\title{
WORKING
}

paper

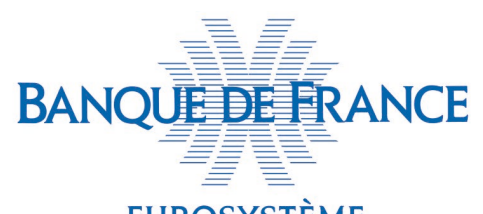

EUROSYSTÈME

\section{Investment and the WACC: new micro evidence for France}

\author{
Juan Carluccio ${ }^{1}$, Clément Mazet-Sonilhac ${ }^{2}$ and \\ Jean-Stéphane Mésonnier ${ }^{3}$
}

February 2018, WP \#710

\begin{abstract}
We exploit a new dataset of consolidated balance sheets for some 1,850, mostly nonlisted, French corporate groups, in order to investigate the relationship between corporate investment and the cost of capital. Our empirical model is motivated by a standard Qtheory of investment and relates the rate of investment to a proxy for profits, the cost of capital and firm- and sector-level controls. We notably construct firm-level measures of the weighted average cost of capital (WACC) that account for industry-specific values of the cost of equity and reflect the actual capital structure of firms. We find a confirmation that a high WACC drags down investment: a one SD increase in the real WACC (+2 pp) is associated on average with a reduction by $0.65 \mathrm{pp}$ in the investment rate. The effect is somewhat larger for manufacturing firms and when firms are highly leveraged or more dependent on external finance. We also investigate the impact of lower competition or higher uncertainty on business investment and do not find evidence in support of any role of these two factors in France in recent years.
\end{abstract}

Keywords: Business Investment, Cost of Capital, Uncertainty, Competition.

JEL classification: G31; G32

\footnotetext{
${ }^{1}$ J. Carluccio: Banque de France (e-mail : juan.carluccio@banque-france.fr)

${ }^{2}$ C. Mazet-Sonilhac: Banque de France and Sciences Po Paris (e-mail : clement.mazet-sonilhac@banquefrance.fr)

${ }^{3}$ J-S. Mésonnier: Banque de France (e-mail : jean-stephane.mesonnier@banque-france.fr)

We thank Marie-Baianne Khder (discussant), Jacques Mairesse, Thomas Philippon, Simon Ray and Patrick Sevestre, as well as the participants in the ECB Workshop on "Euro area business investment in a global context" (June 2017), the 1st workshop of the European Research Network on Investment hosted by the BIS (June 2018) and in seminars at the Banque de France and France Stratégie for their feedback. The views expressed herein are those of the authors and do not necessarily reflect those of the Banque de France or the Eurosystem.
}

Working Papers reflect the opinions of the authors and do not necessarily express the views of the Banque de France. This document is available on publications.banque-france.fr/en 


\section{NON-TECHNICAL SUMMARY}

The weighted average cost of a firm's capital (WACC) is a widely used benchmark for assessing investment opportunities in practice. Survey evidence suggests that a large majority of firms rely on net present value techniques for capital budgeting and that many firms use a firm-level WACC to discount the future cash flows derived form a new investment. However, as firm-level WACC are in general not observable by researchers, empirical evidence of how corporate investment reacts to the WACC is scarce and most studies exploiting firm-level panel data proxy their cost of capital by some interest rate, thereby ignoring the role of the cost of equity (COE) in firms' capital formation decisions. This is inadequate as most firms fund their investments using a mix of equity and debt and the individual WACC may diverge sensibly from a firm's cost of debt. Recently, some observers have indeed blamed "excessive" levels of corporates' COE for the persistent sluggishness of productive investment in developed economies after the 2008 crisis in spite of central banks' success in driving down nominal interest rates to very low levels.

In this paper, we assess the impact of the WACC on corporate investment using new firmlevel data for some 1,850 French, mostly non-listed, non-financial corporate groups from 2005 to 2015. We motivate our empirical model by referring to a standard Q-model of investment, where Tobin's Q appears to be negatively correlated to the firm's WACC. We construct firm-level measures of the WACC that incorporate estimates of the COE based on industry-specific stock market information and a standard dividend-discount model. Controlling for all potentially relevant firm- and sector-level factors, we find new evidence that fluctuations in a firm's WACC matters for investment, notably in the manufacturing sector and for larger firms. Yet, the evidence suggests that the negative impact of the WACC remains contained: a one SD increase in the real WACC (+2 pp) is associated on average with a reduction by $0.67 \mathrm{pp}$ in the investment rate (5\% of its average value). Furthermore, we show that financially more fragile firms or firms that rely more on external finance appear to cut investment more when facing an increase in their cost of capital.

Additionally, our analysis provides useful benchmarks for macroeconomic investment modelling and policy analysis. In particular, this paper relates to the ongoing debate about the causes of the sluggish rate of corporate investment observed in many developed economies in the aftermath of the 2008 crisis. According to our results subdued corporate investment in France over recent years can be traced back to a lower profitability, presumably reflecting depressed demand, and a high cost of capital. 
Figure 1 - The nominal Weighted Average Cost of Capital of French NFCs at the sectorlevel

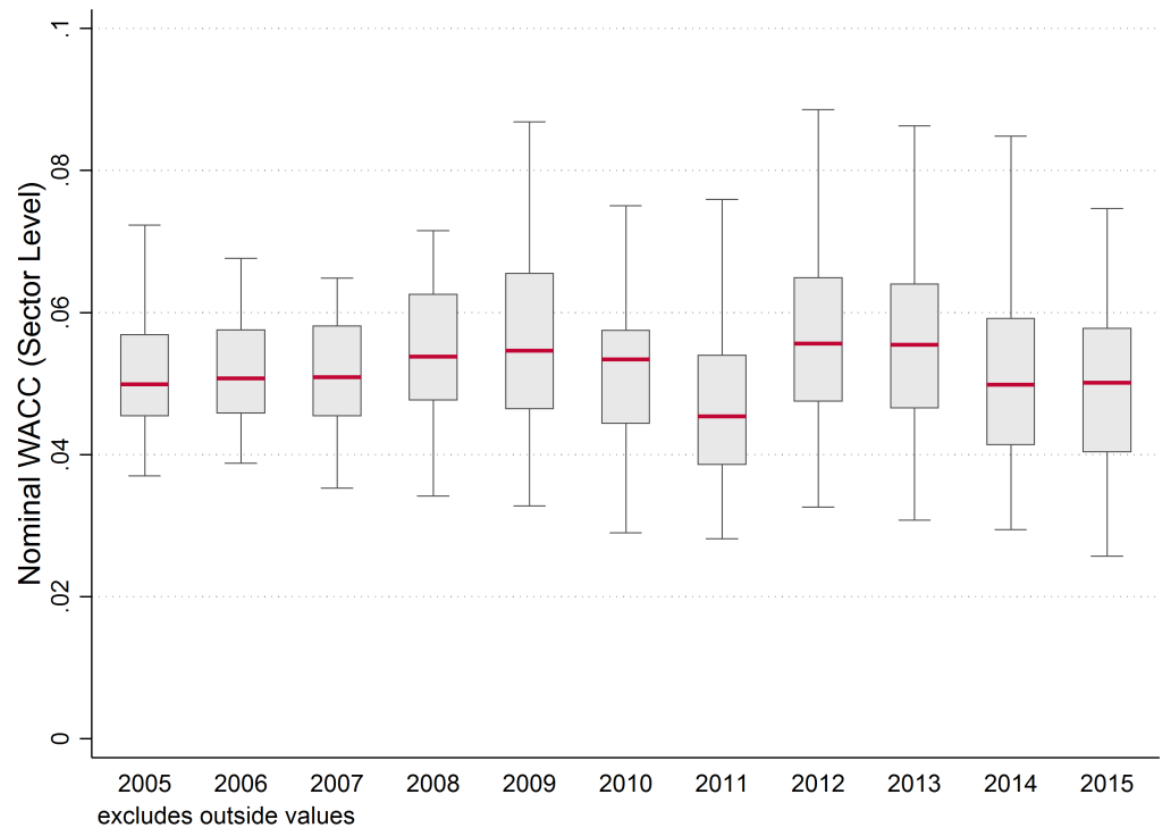

\section{Investissement des entreprises et coût du capital : une étude microéconomique sur données françaises}

\section{RÉSUMÉ}

Dans cet article, nous étudions la relation entre l'investissement des entreprises françaises et leur coût du capital en mobilisant des données comptables de plus de 1850 groupes consolidés, sur la période 2004-2015. Notre démarche empirique s'appuie sur un modèle standard d'investissement, dit de «Q de Tobin », qui relie le taux d'investissement des entreprises à leur profit, leur coût du capital ainsi qu'à des variables de contrôle mesurées au niveau sectoriel. En particulier, nous construisons une mesure du coût moyen pondéré du capital spécifique aux entreprises de notre échantillon. Celui-ci prend en compte le coût des capitaux propres, mesuré au niveau sectoriel ainsi que la structure de capital de l'entreprise. Nos résultats confirment qu'un coût du capital élevé pénalise l'investissement en actifs fixes : une augmentation du coût moyen pondéré du capital de 2 p.p. (un écart type) est associée à une baisse du taux d'investissement de 0.65 p.p. Cet effet se révèle plus important pour les entreprises du secteur manufacturier ainsi que les entreprises contraintes financièrement et celles qui dépendent davantage des sources de financement externes. Finalement, nous étudions le rôle qu'un niveau d'incertitude accru ou qu'un faible niveau de concurrence pourraient avoir joué sur la période récente, mais nos résultats ne nous permettent pas de conclure en faveur d'un impact significatif.

Mots clés : investissement des entreprises, coût du capital, incertitude, concurrence 


\section{Introduction.}

The weighted average cost of a firm's capital (WACC) is a widely used benchmark for assessing investment opportunities in practice. Survey evidence suggests that a large majority of firms rely on net present value (NPV) techniques for capital budgeting and that many firms use a firm-level WACC to discount the future cash flows derived form a new investment (Graham and Harvey, 2001; Kruger et al., 2015). However, as firm-level WACC are in general not observable by researchers, empirical evidence of how corporate investment reacts to the WACC is scarce and most studies exploiting firm-level panel data proxy their cost of capital by some interest rate, thereby ignoring the role of the cost of equity (COE) in firms' capital formation decisions. This is inadequate as most firms fund their investments using a mix of equity and debt and the individual WACC may diverge sensibly from a firm's cost of debt. Recently, some observers have indeed blamed "excessive" levels of corporates' COE for the persistent sluggishness of productive investment in developed economies after the 2008 crisis in spite of central banks' success in driving down nominal interest rates to very low levels. ${ }^{1}$

In this paper, we assess the impact of the WACC on corporate investment using new firm-level data for some 1,850 French, mostly non-listed, non-financial corporate groups from 2005 to 2015. We motivate our empirical model by referring to a standard Q-model of investment, where Tobin's Q appears to be negatively correlated to the firm's WACC. We construct firmlevel measures of the WACC that incorporate estimates of the COE based on industry-specific stock market information and a standard dividend-discount model. Controlling for all potentially relevant firm- and sector-level factors, we find confirmation of a significant impact of the WACC on investment: on average, an increase in the WACC by one standard deviation (+2pp) is associated in our baseline with a decrease in the investment rate by 0.65 percentage points the following year, which corresponds to $5 \%$ of its average value. We also find evidence that this effect is larger in the manufacturing sector, and mostly significant for larger corporations. Last, we find the WACC impinges significantly more on investment when firms are highly leveraged or more dependent on external finance.

Our contribution to the existing literature is twofold. First, while recent papers on the issue focus on (large) listed firms (Frank and Shen, 2016; Melolinna et al., 2018, such as, e.g., ), we find a significant impact of the WACC on corporate investment for a large sample of mostly non-listed corporations. Beyond, we shed light on how the relationship between investment

\footnotetext{
${ }^{1}$ See for instance Galhau et al. (2015) for France and Institute (2016).
} 
and the WACC varies across different size classes of firms. In particular, we find that the negative impact of the WACC is mainly driven by larger firms while teh coefficient becomes no significant when we keep only SMEs.

Second, a key contribution of our study is that we construct a new database of industrylevel, time-varying measures of the COE for some 30 industries, that we then merge with a rich dataset of firm balance sheet with an annual cross-section of some 5,000 listed and nonlisted corporate groups headquartered in France, which is maintained by the Banque de France (FIBEN groupes). ${ }^{2}$ The WACC is by definition an average of the (tax-adjusted) costs of debt and equity funding, weighted by leverage. While the cost of debt is commonly measured by the apparent interest rate paid on existing long-term debt, estimating a firm's COE requires information about its stock price and expected return. As a consequence, researchers tend to either focus on large, listed corporations, or ignore the COE altogether and proxy the cost of capital using a firm-specific or even a macroeconomic measure of the interest rate. We circumvent this problem by mimicking a common practice among financial analysts, who try and guess the cost of capital of a non-listed firm by estimating the COE of similar listed firms in the same industry. We collect stock market information on the almost entire population of French listed non-financial companies (some 600 corporations) and merge it with industry-level profit forecasts from I/B/E/S. For the average listed firm in each industry, we compute a time-varying measure of the COE using a standard dividend-discount model. We then derive a firm-specific WACC for each of the some 1,850 firms in our cleaned dataset of corporate groups by combining our sector-specific estimate of the $\mathrm{COE}$ and firm-specific measures of the tax-adjusted cost of debt and leverage. Although the raw balance sheet data starts in the late 1980s, the scope of the database increased only gradually and we therefore focus our analysis on the period from 2004 to 2015 when data coverage is deemed stable enough. On average in our sample, the (nominal) WACC stands at 5.6\%, well above the tax-adjusted cost of debt (3.1\%) or even the apparent interest rate paid by firms $(4.4 \%)$, while the COE hovers at close to $8 \%$. However, the dispersion of the WACC is quite high, with extreme percentiles at $2.5 \%$ and $11.5 \%$ respectively, and time-varying (cf. Figure 2).

Our empirical analysis of the relationship between corporate investment and the WACC is motivated by a standard Q-model of investment as in Frank and Shen (2016) and Gutierrez and Philippon (2016), where Tobin's Q is further decomposed under simplifying assumptions into a linear function of an expected profitability component and a cost of capital component fol-

\footnotetext{
${ }^{2}$ This dataset of sector-level COE and WACC is readily available for researchers upon request and will be updated regularly.
} 
lowing the approximations in Abel and Blanchard (1986). We therefore basically regress the investment rate of the firms in our panel on a measure of their profitability and our estimate of the WACC. We control for standard potentially confounding factors at the firm-level, notably including size and leverage as proxies for financial frictions (as, e.g., in De Socio and Sette (2018)), and at the sector-level. We notably include in our regressions industry-specific measures of within-sector competition and uncertainty, that we construct separately as, respectively, the Herfindahl index of firm sales and the dispersion of ROA in each sector for a large population of non-consolidated firms. ${ }^{3}$ Last, we control for unobserved firm characteristics using firm fixed-effects and for macroeconomic fluctuations using year fixed-effects or macro controls.

Our estimation results first confirm that the level of the WACC matters for investment. According to our baseline specification, an increase of the (real) WACC by one standard deviation (2.0 percentage points) leads the following year to a decrease in the investment rate by 0.65 percentage points. This effects is however stronger when looking at the manufacturing sector only: a one SD increase in the WACC is then associated with a decline in the investment rate of close to $1 \mathrm{pp}$. We also look at heterogeneous effects across size classes of firms. We find that the WACC coefficient is more precisely estimated for large and medium-sized firms than for SMEs. Last, we explore non-linear effects of heterogeneous financial constraints faced by firms. As intuition would suggest, we find that investment reacts more negatively to a higher WACC when the firm is already highly-leveraged or when it belongs to an industry where capital expenditure relies more on external funding.

In all our regressions, we mitigate possible endogeneity issues by lagging all the firm- and sector-level regressors. However, one may still be concerned that measures of both the WACC and the leverage of the firm may be influenced by announced and/or planned investments that will only take place the next year. As a robustness check, we therefore re-estimate our main regression with firm fixed-effects using a GMM estimator, whereby we instrument the lagged WACC and leverage with up to their fourth lag. As this setup requires at least six observations for each firm, our sample then shrinks by two thirds and is mostly confined to the post-2008 period, which limits our investigations. Using GMM, the estimated coefficient of the WACC comes out as strongly negative and more than 5 times larger than in our baseline. This suggests

\footnotetext{
${ }^{3}$ We use Banque de France's FIBEN database to construct these variables. The FIBEN database covers all resident legal units with total sales above EUR 0.75 million that publish detailed accounts. Reporting firms account for roughly $70 \%$ of the value added of NFCs in France and for a share of employment above $75 \%$ in almost all industries.
} 
that potential reverse causality, if any, is likely to imply a bias towards zero of the WACC coefficient in the baseline OLS regressions. Our baseline estimate of the WACC coefficient should therefore be viewed as rather conservative.

We contribute to the abundant empirical literature on productive investment and the cost of capital by focusing on the WACC and providing new quantitative estimates for France. Existing empirical models are broadly speaking of two sorts: the role of the cost of capital for investment is either derived from a Hall-Jorgenson User-Cost-of-Capital (UCC) approach, or from a Tobin's Q model. ${ }^{4}$ Although the theoretical motivations are different, empirical models most often end up including a fairly similar set of regressors. A major difference is that, under the UCC approach, the WACC comes up in the regression multiplied by the time-varying ratio of the price of investment to the price of value added. This makes however little difference over time periods when this ratio is quite stable, as was the case in France over the last decade or so. ${ }^{5}$ We follow on Frank and Shen (2016) insofar as we compute the COE using a dividenddiscount approach and not the CAPM. However, while they exploit Compustat data on some 10,000 listed, hence rather large, US corporations over some 50 years, we focus on a shorter time span but cover a larger variety of French firms, as listed firms in our sample account for only $10 \%$ of the total and one half of our firm-year observations relate to SMEs. Last, contrary to other recent studies notably using US data (Gutierrez and Philippon, 2017; Gulen and Ion, 2016), we do not find any evidence supporting a role for an increased concentration or heightened uncertainty in explaining investment patterns in France since the mid-2000s.

The paper is organized as follows. Section II motivates the empirical model. Section III presents our data and explains the construction of our firm and industry-level variables. Section IV details our results. The last section concludes.

\section{Model.}

We follow Frank and Shen (2016) and Abel and Blanchard (1986) and derive our empirical specification of the investment equation from a standard Tobin's Q model of optimal capitalbudgeting at the firm level. We use here the same notation as Frank and Shen (2016). ${ }^{6}$ We

\footnotetext{
${ }^{4}$ Melolinna et al. (2018) is a recent example of the former approach for the UK and Crépon and Gianella (2001) an older one for France. Frank and Shen (2016), which is the closest paper to ours, is an example of the second approach.

${ }^{5}$ As in other developed economies, this ratio trended down markedly over the 1990s and early 2000s.

${ }^{6}$ For a detailed derivation of the model, please see Frank and Shen (2016) or Abel and Blanchard (1986).
} 
define $V(.,$.$) as the value of an infinitely-lived representative firm, K_{t}$ and $I_{t}$ respectively denote the stock of capital and the firm's net purchases of fixed assets. Capital depreciates at rate $\delta \in[0 ; 1], r_{t}$ is the weighted average cost of capital (i.e. the discount rate for future cash-flows). $\pi(.,$.$) is the revenue in a period and c(.,$.$) is the quadratic capital adjustment cost function with$ parameter $\Phi \geq 0$. The firm faces a quadratic capital adjustment cost which is homogeneous in $I_{t}$ and $K_{t}$ :

$$
c\left(I_{t}, K_{t}\right)=I_{t}+\frac{\Phi}{2}\left(\frac{I_{t}}{K_{t}}\right)^{2} K_{t}
$$

Investment increases fixed assets according to a standard capital accumulation process:

$$
K_{t+1}=K_{t}(1-\delta)+I_{t}
$$

At each period, the firm chooses the optimal level of $I_{t}$ in order to maximize its expected net present value, with respect to $\Gamma_{t}$, the set of information available at time $t$, and $a_{t}$, which represents a shock to firm profits. Thus, the firm program writes:

$$
V\left(a_{t}, K_{t}\right)=\mathbb{E}\left\{\sum_{j=0}^{\infty} \frac{\pi\left(a_{t+j}, K_{t+j}\right)-c\left(I_{t+j}, K_{t+j}\right)}{\Pi_{s=1}^{j}\left(1+r_{t+s}\right)} \mid \Gamma_{t}\right\}
$$

If we derive the first order condition with respect to $K_{t}$, we find that the optimal $I_{t}$ is such that:

$$
\frac{I_{t}}{K_{t}}=\frac{1}{\Phi}(\underbrace{\mathbb{E}\left\{\sum_{j=1}^{\infty}(1-\delta)^{j-1} \frac{\pi_{K}\left(a_{t+j}, K_{t+j}\right)-c_{K}\left(I_{t+j}, K_{t+j}\right)}{\Pi_{s=1}^{j}\left(1+r_{t+s}\right)} \mid \Gamma_{t}\right\}}_{=q_{t}}-1)
$$

where $q_{t}$ is the standard marginal Tobin's Q, i.e. the expected marginal discounted profit associated with one more unit of capital. Equation (1) simply states that this marginal benefit is equal to the marginal cost at equilibrium. It is standard practice in empirical work to proxy the firm's marginal Q with its average $Q$, although this is vindicated in theory only under very strict conditions Hayashi (1982). Average Q is then commonly measured as the ratio of the market value to the book value of the firm's assets (Gutierrez and Philippon, 2016, cf., e.g., ).

As our sample mainly consists of non-listed firms, we cannot observe their average Q. Furthermore, we are mostly interested in highlighting the role of the WACC, which is the relevant discount rate $r_{t}$ in equation (1). We therefore follow Abel and Blanchard (1986) and Frank and Shen (2016) to derive under simplifying assumptions an expression of Tobin's Q as a linear function of the firm's expected profits and its WACC. The two most important underlying as- 
sumptions are here i) that the dynamics of the one-period discount factor and the one-period marginal product of capital can be described as AR(1) processes and ii) that the marginal future profit rate can be approximated by the observable average profit rate, here the earning before interest, debt, taxes and amortization (i.e. EBIDTA) over the capital stock. Decomposing the weighted average cost of capital into the leverage $L_{t}$ defined as Gross Debt / (Gross Debt + Equity), the cost of equity $\operatorname{CoE}_{t}$ and the cost of debt $\operatorname{CoD}_{t}$ and $\tau$ the corporate tax rate, the investment equation then reads:

$$
\frac{I_{t}}{K_{t-1}}=\beta_{0}+\beta_{1} \frac{E B I T D A_{t}}{K_{t-1}}+\beta_{2}(\underbrace{L_{t}(1-\tau) C_{t} D_{t}+\left(1-L_{t}\right) C o E_{t}}_{=W A C C_{t}})
$$

Frank and Shen (ibid.) show that $\beta_{1}$ is strictly positive and reflects the impact of all future marginal profit shocks on investment decisions, while the coefficient $\beta_{2}$ of the WACC is strictly negative when the cost of equity is measured using a dividend-discount method.

We finally augment this simple equation with several firm and sector controls as well as firm and year-fixed effects to get our baseline specification:

$$
\frac{I_{i, t}}{K_{i, t-1}}=\beta_{0}+\beta_{1} \frac{E B I T D A_{i, t-1}}{K_{i, t-2}}+\beta_{2} W A C C_{i, t-1}+\beta_{3} \mathbf{X}_{i, t-1}+\beta_{4} \mathbf{Z}_{s, t_{1}}+\delta_{i}+\gamma_{t}
$$

where the firm-level controls in $X_{i, t-1}$ include : leverage as a proxy for financial frictions, sales growth as an additional control for demand, firm size (log of total assets), the firm's depreciation rate of capital and a (contemporaneous) dummy for mergers and acquisitions, and the sector-level controls in $Z_{s, t_{1}}$ include industry-specific time-varying measures of concentration and uncertainty which we construct as explained below in section III.

\section{Data.}

A. Data sources and construction of the main variables.

To construct our dataset, we use three different sources of information: consolidated accounting information for a large sample of French corporate groups from the Banque de France's FIBENgroupes database, stock market information for listed French corporations from Datastream, non-consolidated income statements for French enterprises from Banque de France's FIBEN database. 
Consolidated balance sheet data. We draw consolidated balance sheet and income statement data for non-financial French groups from the annual consolidated FIBEN-groupes database. The raw database covers the period between 1988 and 2017. Consolidation is an accounting method used by corporate groups composed of several legal entities in order to publish a combined statement that shows the financial position of the holding company and its subsidiaries. This is a compact and accurate picture of the financial position of the whole group. Using consolidated data is a clear advantage for anyone who aims to relate corporate investment to the cost of capital. Indeed, when several legal entities are part of a same group, investment and financing decisions may be undertaken globally at the top by the parent company. In this case, intra-group lending and partition of investment may lead to noisy measures of investment and biases at the subsidiary-level. The consolidated FIBEN database is strongly unbalanced over this period in part because consolidation is only mandatory for listed groups and groups with characteristics (size, turnover, number of employees) above a legal threshold. ${ }^{7}$ In some cases, consolidation is not mandatory but is done on a voluntary basis, for transparency reasons, essentially in order to get a Banque de France investment grade. Our raw consolidated database gathers 98,204 group-year observations and 13,387 distinct groups. There are only 14 and 31 observations in 1988 and 2017 respectively and more than 5000 observations per year from 2009 to 2013.

We define net fixed assets as the sum of net tangible assets (which include leasing) and net intangibles. The gross investment rate is defined as net capital expenditure in fixed assets (acquisition minus sales) divided by the stock of lagged net fixed assets. The net investment rate is equal to the gross investment rate minus the depreciation of fixed assets over lagged net fixed assets. Depreciation is defined as net depreciation and provisions. We define profitability as the ratio of EBITDA to lagged net fixed assets. Firm size is the log of total assets. We use firm book financial leverage defined as financial debt over financial debt plus book equity as the main measure of leverage for non-listed firms. For listed firms, we use the market leverage and replace the book value of equity by its market value. Last, we construct a dummy variable for M\&A activities which equals one if a merger or acquisition operation takes place in the year and exceeds in value $10 \%$ of lagged fixed assets of the acquirer.

\footnotetext{
${ }^{7}$ Before 2016, consolidated reporting is required for groups with total assets above EUR 15 mns, net income above EUR $30 \mathrm{mns}$ and staff above 250. From 2016 on, these threshold become EUR $24 \mathrm{~ms}$, EUR 48 mns and 250 employees respectively. Consolidated reporting is mandatory if the group exceeded two of these three thresholds in year 1 or year 2 .
} 
Cost of equity, cost of debt and the weighted average cost of capital. Due to the lack of data on stock prices, dividends and expected profit growth rates for non-listed firms which make up most of our sample, we compute the cost of equity at the sector level using data on almost all listed French firms. ${ }^{8}$ The motivation for doing this is the standard practice of valuing a non-listed firm by comparing it to listed firms in the same industry. We therefore assume that the cost of equity faced by a firm in a given industry is close to the average cost of equity for listed firms in the same industry. The sector-specific cost of equity is estimated using a H-model version of the standard dividend discount (DDM) model (Fuller and Hsia, 1984), where expected cash flows to shareholders include dividends from French listed companies of the given sector. We sort on average 500 listed French firms per year into 31 sectors (resulting from the matching of NACE rev. 2, A38 classification with the rougher nomenclature of stock market industries reported by Datastream) and compute the sector specific dividend yield each year as the weighted average by market capitalization of the dividend yields of individual firms belonging to this sector. Estimating the cost of equity with a H-DDM also requires short and long run forecasts of the future dividend growth of firms in the sector. Assuming constant dividend payout rates, we proxy these forecasts using respectively the sector-specific I/B/E/S profit growth forecasts at the 3-5 year horizon and the long-run nominal GDP growth forecasts from the Euro-system Survey of Professional Forecasters (whereby long-run nominal GDP growth is proxied as the sum of long-run real GDP growth and long-run headline HICP inflation). We assume that the growth rate of expected future dividends converges from its short-run towards its long-run value over a period of $\mathrm{H}=10$ years. Because the cost of equity is by essence a forward looking measure and that we use market data measured at the end of each year, we define the contemporary cost of equity (at time $t$ ) as the cost of equity computed at the beginning of the period (i.e. at the end of period $\mathrm{t}-1$ ).

$$
C o E_{s, t}=\left(\frac{D}{M V}\right)_{s, t-1}\left[\left(1+g_{s, t-1}^{L T}\right)+\frac{H}{2}\left(g_{s, t-1}^{S T}-g_{s, t-1}^{L T}\right)\right]+g_{s, t-1}^{L T}
$$

where $\left(\frac{D}{M V}\right)_{s, t-1}$ is the sector $s$ weighted average dividend yield at the beginning of period $\mathrm{t}$ (time $t-1$ ). As I/B/E/S does not define sectors on the basis of the NACE, we match $\mathrm{I} / \mathrm{B} / \mathrm{E} / \mathrm{S}$ and NACE rev. 2 classification.

The firm-specific cost of debt is measured as the apparent cost of debt (interest paid over total financial debt) and computed from income statements and balance-sheet data. The weighted average cost of capital (WACC) is then computed as:

\footnotetext{
${ }^{8}$ Our data set covers some 600 individual stocks listed on all the main French stock exchanges
} 


$$
\begin{aligned}
\mathrm{WACC}_{i \in s, t} & =\frac{E_{i, t}}{V_{i, t}} \times \mathrm{CoE}_{s, t} \\
& +\frac{D_{i, t}}{V_{i, t}} \times\left[\left(1-\tau_{s, t}\right) \times \mathrm{CoD}_{i, t}\right]
\end{aligned}
$$

where $E$ stands for the market value of equity (when available, otherwise the book value of equity is used for non-listed firms), $D$ for the book value of financial debt and $V=E+D$ for the total market value of the firms external financing (book value for non-listed firms). $\tau$ is the effective tax rate on corporations. As firm-specific apparent income tax rates are very volatile, we use the average income tax rate of firms in the same size category (SMEs vs larger) and the same sector as a proxy for a firms rate (keeping only firms with non-negative average fiscal rate).

Last but not least, note that all real cost variables are derived from nominal cost variables using French core HICP inflation as a proxy for expected inflation. ${ }^{9}$

Sector-level measures of competition and uncertainty. We also construct sector-level measures of competition and uncertainty. Regarding competition, our baseline indicator is the sector-level Herfindhal index of firms sales, which we compute using income statement data from the FIBEN database on French legal entities (in contrast to consolidated group data). We resort to this database for two reasons: first, it covers a much broader number of firms (some 250,000 a year, accounting for some $70 \%$ of the value added of French non-financial corporations) and second, the notion of sector is more accurate for legal entities than it is for groups which are more likely to combine production activities across different sectors. Regarding uncertainty, our baseline indicator is the dispersion of firms' ROA (net income over lagged total assets) within a given year and sector.

\section{B. Data cleaning}

Some cleaning is required to obtain our working sample. We start by deleting groups which belong to the farming, public administration, financial, real estate and healthcare sectors. We require that all group-year observations have non-missing data for total assets, fixed assets and book equity, investment in fixed assets, financial debt and EBITDA. We only keep group-year observations with positive equity, debt and total assets. We impose ratios of gross debt over

\footnotetext{
${ }^{9}$ Since our baseline regressions include year-fixed effects, the choice of the deflator of nominal cost variables should not matter for our results as long as we use a nation-wide measure of inflation.
} 
total assets, depreciation over total asset and interests paid on debt over financial debt to lie in the close interval $[0 ; 1]$. We consider only the ultimate level of consolidation when several layers and definitions of the group coexist in the data. We keep only groups with always strictly positive gross investment rates and delete groups with quasi-zero gross investment rates. ${ }^{10}$ For this purpose, and considering the unbalanced nature of our panel, we first regress gross investment rates on year dummies and define firms with quasi-zero gross investment rates as firms with average residual values below the $10 t h$ percentile. Last, gross and net investment rates, profitability and the costs of equity and debt are trimmed at the 1st and 99th percentiles in order to mitigate the effect of outliers. Finally, we only keep observations for the years 2003-2015 due to the low number of clean observations in our database before this period and impose that a group appears for at least three consecutive years in the sample.

\section{Descriptive statistics.}

We end-up with a sample of 8,819 group-years observations and 1,847 unique groups, of which only 182 are listed. The average group is present in our sample 5.5 years in a row. 72 unique groups are very large ones (textitGrandes entreprises), 1168 are large (textitEntreprises de taille intermédiaire) and 796 are SMEs. Interestingly, about $43 \%$ of the firms in our sample are categorized as Small and Medium-sized Enterprises (SMEs). Our size classification follows the definition set by the French LME law of 2008 with respect to total assets and turnover thresholds (but not to the number of employees, which is often missing in the data). ${ }^{11}$ Figure 1 provides some external validity for our sample. We plot the aggregated gross investment rate over the period 2004-2015 for the firms in our sample against the macroeconomic investment rate for French non-financial corporations. Our aggregated measure of corporate groups' investment rate displays somewhat larger values across time, from around $8 \%$ in 2004 to more than $14 \%$ in 2008 , but exhibits relatively similar trends and variations as the macro measure. Last, note that our estimation sample is still strongly unbalanced with a changing firm-size composition which may affect some aggregated statistics but not our estimations as far as we

\footnotetext{
${ }^{10}$ Capital expenditures tend to be discontinuous for small firms as many small firms do not invest every year and as many zeros appear to be "false"" missing values. Dealing properly with the truncated nature of the dependent variable would then call for a Tobit regression. However, as we consider corporate groups instead of individual firms, therefore relatively large SMEs and larger corporations, we hardly ever observe zero and quasi-zero gross investment rates in our dataset. We therefore prefer to clean up the data from these firms and keep continuously investing firms. If we do not proceed to this cleaning, we end up with a slightly larger sample and our results remain identical (tables upon request)

${ }^{11}$ To sort corporate groups into legal size categories, we apply the legal sales and assets thresholds using consolidated balance sheets and income statements. According to the 2008 LME law, SMEs are defined as firms with less than 250 staff and annual sales below 50 EUR million or assets below 43 EUR million. All the firms above these thresholds are categorized as mid-size or large corporations (staff above 5,000).
} 
control with firm and year fixed-effects. However, the rotating nature of our panel of firms prevents us from comparing regression results for different sub-periods.

Table 1 provides descriptive statistics. All variables have reasonable average values and exhibit a large degree of dispersion across firms and years. At $12.9 \%$, the average investment rate is close to its macro equivalent computed using National accounts data (around 12\%). In spite of the restrictions imposed on the sample for cleaning purpose, the investment behavior of firms in our sample remains quite diverse: firms in the first decile of the distribution invest less than $3 \%$ of their fixed assets, whereas firms in the last decile invest more than $27 \%$ of their fixed assets every year. Leverage is on average contained in our sample, at $42 \%$, also broadly in line with macro estimates for France (close to 50\%). On average, our estimated nominal COE noses at $7.8 \%$, while the (pre-tax) apparent cost of corporate debt hovers at $4.3 \%$. Our estimate of the average income tax rate, at $31 \%$, is close to the official tax rate on corporate income in France over the period (33.3\% for the most general case). In our regressions, nominal returns are deflated using the French core CPI as a proxy for inflation expectations. Figures 2, 3 and 4 show boxplots of the sector-level real WACC, COE and cost of debt respectively. The crossindustry dispersion of the COE comes out as larger than the dispersion of the costs of debt and it increased markedly during crises periods (2009 and 2012).

Finally, figures 5 and 6 show the distribution through time of our measures of industry-level concentration and uncertainty. No clear trend emerges regarding concentration over the 20052015 decade. Median concentration dropped during the 2008 crisis, before returning gradually to its pre-cisis level. Median uncertainty remained fairly flat over the decade. However, the dispersion of uncertainty across industries increased sharply with the subprime crisis and became very skewed to the right. Interestingly, the dispersion of our sector-level measure of uncertainty broadly follows the pattern of commonly used macroeconomic measures of uncertainty, such as the stochastic volatility of options on stock market indexes (such as the VSTOXX for Europe).

\section{Results.}

\section{A. Baseline specification}

This section details our results. We first consider the whole sample of corporate groups in our cleaned dataset, which is mostly populated by non-listed firms. The results for our baseline regression are shown in column 2 of Table 2. Controlling for both firm and time fixed effects, as well as various relevant firm and sector characteristics, we find that the investment rate neg- 
atively correlates with the lagged WACC. Our main coefficient of interest, -0.33 , is similar to what Frank and Shen (2016) find for their sample of listed US corporations when they estimate the cost of equity using similar methods: between -0.22 and $-0.57 .{ }^{12}$ It is somewhat larger than what Melolinna et al. (2018) put forward for a smaller sample of UK listed firms (some -0.15 ). As our additional regressions on firm sub-groupings by size suggest (see below), this discrepancy may however be accounted for by the large proportion of small, non-listed corporations in our sample. In economic terms, an increase in the real WACC by one standard deviation (2\%) is associated with a decrease in the investment rate by 0.65 percentage points, i.e., about $5 \%$ of the sample average investment rate.

As expected, investment also positively co-moves with the level of lagged cash flows, which we use as a proxy for expected profitability: as the ratio of gross operating income to fixed assets increases by one standard deviation (42\%), the investment rate improves by some 2.5 percentage points (i.e., almost one fifth of the average rate). This rather strong effect, combined with the positive coefficient associated with lagged sales growth, tends to confirm the common view that demand stands as the main driver of investment.

Last, we find that lagged leverage drags investment significantly down, pointing to an active role for financial frictions with lenders. More precisely, a higher leverage by one standard deviation $(21 \%)$ decreases the investment rate by some 4 percentage points. Note that these coefficients remain quite stable as time fixed effects and additional time-varying firm-level controls are included as regressors alongside the firm fixed effects.

In columns 4-7 of Table 2, we then look at the impact on investment of the individual components of the lagged WACC: the (tax-adjusted) real cost of debt, the real cost of equity (while still controlling for leverage). We first consider each of these two variables separately (as if the firms in our sample were entirely funded with either debt or equity), then we include them together as they show up in the formula of the WACC (i.e., leverage-adjusted). This exercise confirms that the real cost of debt is also strongly negatively correlated with investment, as is often found in empirical studies where the cost of capital is assumed to be equal to a relevant real interest rate. In economic terms, we find that using the cost of debt as a proxy for the cost of capital does not change much our perception of the latter's impact on investment: in economic terms, an increase in the tax-adjusted real interest rate on debt by one standard deviation (3.0\%) decreases investment by 0.8 percentage points (i.e., by $6.3 \%$ of the average investment rate). However, one shall keep in mind that the real WACC and the (tax-adjusted) real cost of debt are only loosely correlated within-firm: an increase of the second by 1 percentage point

${ }^{12}$ See their table 9. 
is associated with an increase in the former by less than 0.2 percentage point. The real (unlevered) cost of equity also significantly negatively affects investment when taken in isolation, but the size of the effect is somewhat smaller $(-0.5 \%$ for a increase by one SD). Last, as column 5 shows, including both components of the WACC in the same regression yields a coefficient for the leverage-and-tax-adjusted real cost of debt which is an order of magnitude larger as before, in line with results in Frank and Shen (2016). This is also consistent with intuition since leverage is on average low (43\%), and therefore contributes to dwarfing fluctuations in the cost of debt.

In all the regressions discussed above, we also included our measures of sector-specific concentration and uncertainty. Recent contributions have indeed pointed to a role for lower competition and heightened uncertainty in dampening firms'investment. For instance, Gutierrez and Philippon (2016) and Gutierrez and Philippon (2017) show that a declining degree of competition across a large number of industries is partly responsible for their finding that US listed corporates have under-invested relative to their Tobin's Q since the early 2000s. Regarding the role of uncertainty, Bussiere et al. (2015) find at the macro level for a panel of 22 advanced economies over 1996-2014 that macroeconomic uncertainty weighed down on investment globally, although they stress that insufficient perceived aggregate demand remained its main driver. Interestingly however, our results do not support such claims, at least for France since the mid2000s. We do not find any effect of a lower degree of within-sector competition on investment. Similarly, uncertainty does not seem to have played any significant role in firms' investment in France over the last decade, at least beyond effects already captured in other firm-level variables such as firm sales growth and profits. Importantly, these conclusions still hold whether timefixed effects are included in the regression or not: indeed, as previous studies mostly look at macro measures of uncertainty with a strong time-varying volatility -such as, e.g., the US VIX index or the Economic Policy Uncertainty (EPU) index of Baker et al. (2014)- one may expect time-fixed effects to absorb part of the variance explained by our sector-level measure of uncertainty.

\section{B. Additional results: exploring non-linearities}

In this section, we shed light on how the relationship between investment and the WACC shifts for different industrial sectors, size classes of firms and the degree to which firms face financial frictions.

We first focus on two broadly defined sectors, manufacturing and retail, which are the most 
heavily represented in our data with 911 and 826 firms respectively. ${ }^{13}$ As shown in columns 2 and 3 of table 3, we find a much larger coefficient of the WACC for manufacturing firms than in the baseline, and a one SD (2 pp) increase in the WACC now yields a decrease in the investment rate by almost $1 \mathrm{pp}$. In contrast, investment seems not to react to fluctuations in the WACC in the retail sector.

Since our sample of firms covers a large number of small, non-listed groups, we can also shed light on how the relationship between investment and the WACC shifts for different size classes of firms. Columns 4 and 5 of table 3 presents the results of additional regressions that we run either on small groups, i.e. groups falling into the legal definition of SMEs, or larger ones. We find that larger firms alone drive our baseline result. The coefficient of the WACC seems larger for SMEs, but it is very imprecisely estimated. This result may reflect the fact that there are only half as many observations for SMEs in our sample than for larger groups, which is likely to weaken the significance of our estimates. ${ }^{14}$

Last, we test whether the impact of the WACC on capital expenditure depends on the degree of financial constraints faced by the firm. For this purpose, we consider two simple measures of financial constraints: a dummy for high leverage and a measure of dependence on external finance. First, we sort each year all firms according to their leverage the year before and define firms in the last quartile of the lagged leverage distribution as highly-leveraged. Second, we use an updated version of the Rajan-Zingales (RZ) index of financial dependence at the industry level. Rajan and Zingales (1998) define financial dependence at the firm-level as the share of capital expenditures which is not funded by the firm's cash flows (hence funded externally). The industry-level equivalent is computed as the median index across firms in each industry. The genuine index was computed using Compustat data on US listed corporations over the 1980s. In order to account for structural changes that occurred within non-financial industries and in the financial sector since then, we prefer to use an updated version of the RZ index which was computed by Guevara and Maudos (2011) for UK listed firms over 1993-2003. We then sort industries according to their degree of dependence on external finance and define as ex ante more financially dependent firms that belong to industries in the upper half of this distribution. Columns 6 and 7 of table 3 show the results. We find evidence that the negative effect of a higher WACC on investment is much stronger and more significant for highly-leveraged firms:

\footnotetext{
${ }^{13}$ Manufacturing is defined as NACE rev 2-sector C and retail as NACE rev 2-sector G.

${ }^{14}$ Another potential explanation could be that our measures of the COE and the WACC are less relevant for small firms. According to a recent issue of the European Investment Bank's Investment Survey (EIB, 2018), small businesses are less likely to rely on standard CAPM or DDM methods to evaluate their cost of capital as neither their financing choices nor their investment decisions and timing compare to those of large listed group
} 
a $2 \mathrm{pp}$ increase in the WACC now leads to a reduction in capital expenditures by $1.6 \mathrm{pp}$ for such firms, i.e. above three times more than for less leveraged ones. Similarly, our regression results point to a stronger effect of the WACC on investment when firms are more dependent on external finance. Overall, our findings support the intuition that a higher cost of capital is more likely to curb investment when the firm is already more financially constrained.

\section{Robustness}

A general concern with panel regressions like (2) is that the main coefficient of interest may be biased due to some endogeneity of the cost of capital, to the firm's investment plans. This concern is partly alleviated here inasmuch as we lag all our regressors by one year. However, one may argue that this is not enough to ensure exogeneity. For instance, firms facing less profitable investment opportunities in a given year may also be perceived as becoming riskier and face a higher credit premium, which would bias the estimated coefficient of the WACC upward in absolute terms. Alternatively, firms may pre-fund planned investment on a given year but book the capital expenditure only the following year, which would bias the coefficient downward in absolute terms. Similarly, the coefficient of leverage is likely to be biased due to endogeneity problems. To deal more explicitly with this issue, we re-estimate our baseline regression using a generalized-method-of-moments (GMM), two-stage least squares approach, where we instrument the (lagged) WACC with its 3rd and 4th lags and the (lagged) leverage with its 2 nd and 3rd lags. ${ }^{15}$ Implementing this method implies a sharp reduction in the sample size since more than six consecutive observations are required for each firms. Furthermore, since the coverage of the initial database increases with time, the remaining sample is concentrated on the post-2009 period.

Table 4 presents the results of the GMM regressions. For comparison purpose, columns 1 and 2 show the results of OLS regressions when the sample is reduced to the data used for the GMM regressions. Due to the smaller size of the sample (almost three times smaller), the WACC coefficient is not significant anymore but still of the same magnitude as before. Columns 3 and 4 show the results of the GMM regressions. Comparing both columns confirms that about $90 \%$ of the data used are posterior to the 2008 crisis when restricting the estimation sample to longer individual spells of at least six consecutive observations. The GMM estimator of the WACC coefficient is still significantly negative and close to six times larger than in the baseline case,

\footnotetext{
${ }^{15} \mathrm{We}$ tried many combinations of lags of the two endogenous variables as well as lags of the cost of debt and equity and their variations and based our final choice on the results of usual statistical test of validity and strength of the instruments.
} 
suggesting that the OLS estimator is biased towards zero. Weighing the benefits of a larger sample against the costs of a potential attenuation bias, we prefer to keep the OLS results as our baseline and to present them as rather conservative.

\section{Conclusion.}

In this paper, we evaluate the effects of the cost of capital on productive investment for a large sample of mostly non-listed French corporate groups over the 2005-2015 decade, including a large proportion of SMEs. Our results therefore adds to the large body of empirical work using either macro series or micro-data on large, listed firms. We find new evidence that fluctuations in a firm's WACC matters for investment, notably in the manufacturing sector and for larger firms. Yet, the evidence suggests that the negative impact of the WACC remains contained: a one SD increase in the real WACC ( $+2 \mathrm{pp})$ is associated on average with a reduction by $0.67 \mathrm{pp}$ in the investment rate (5\% of its average value). Furthermore, we show that financially more fragile firms or firms that rely more on external finance appear to cut investment more when facing an increase in their cost of capital.

Additionally, our estimates provide useful benchmarks for macroeconomic investment modeling and policy analysis. In particular, this paper relates to the ongoing debate about the causes of the sluggish rate of corporate investment observed in many developed economies in the aftermath of the 2008 crisis. According to our results subdued corporate investment in France over recent years can be traced back to a lower profitability, presumably reflecting depressed demand, and a high cost of capital, while neither uncertainty per se nor insufficient competition seem to have played any major role. 


\section{References}

Abel, Andrew B. and Olivier J. Blanchard, 1986, The Present Value of Profits and Cyclical Movements in Investment, Econometrica 54.2, 249-273.

Baker, Scott, Nicholas Bloom, Brandice Canes-Wrone, Steven Davis, and Jonathan Rodden, 2014, Why Has US Policy Uncertainty Risen since 1960?, American Economic Review $104.5,56-60$.

Bussiere, Matthieu, Laurent Ferrara, and Juliana Milovich, 2015, Explaining the Recent Slump in Investment: the Role of Expected Demand and Uncertainty, Working papers, Banque de France.

Crépon, Bruno and Christian Gianella, 2001, Fiscalité et coût d'usage du capital: incidences sur l'investissement, l'activité et l'emploi, Economie et Statistique 341.1, 107-128.

De Socio, Antonio and Enrico Sette, 2018, Firms' investments during two crises, Temi di discussione (Economic working papers) 1173, Bank of Italy, Economic Research and International Relations Area.

Frank, Murray and Tao Shen, 2016, Investment and the weighted average cost of capital, Journal of Financial Economics 119.2, 300-315.

Fuller, R.J. and C. Hsia, 1984, A simplified common stock valuation model, Financial Analysts Journal 40.5, 49-56.

Galhau, F. Villeroy de, L. Guerin, and A. Hautier, 2015, Rapport d'étape au Premier ministre : le financement de l'investissement des entreprises, tech. rep.

Graham, John R. and Campbell Harvey, 2001, The theory and practice of corporate finance: evidence from the field, Journal of Financial Economics 60.2-3, 187-243.

Guevara, Juan Fernndez de and Joaquin Maudos, 2011, Banking competition and economic growth: cross-country evidence, The European Journal of Finance 17.8, 739-764.

Gulen, Huseyin and Mihai Ion, 2016, Policy Uncertainty and Corporate Investment, Review of Financial Studies 29.3, 523-564.

Gutierrez, German and Thomas Philippon, 2016, Investment-less Growth: An Empirical Investigation, CEPR Discussion Papers 11673, C.E.P.R. Discussion Papers.

Gutierrez, German and Thomas Philippon, 2017, Declining Competition and Investment in the U.S, NBER Working Papers 23583, National Bureau of Economic Research, Inc.

Hayashi, Fumio, 1982, Tobin's Marginal q and Average q: A Neoclassical Interpretation, Econometrica 50.1, 213-24.

Institute, McKinsey Global, 2016, Diminishing returns: why investors may need to lower their expectations, tech. rep. May. 
Kruger, Philipp, Augustin Landier, and David Thesmar, 2015, The WACC Fallacy: The Real Effects of Using a Unique Discount Rate, Journal of Finance 70.3, 1253-1285.

Melolinna, Marko, Srdan Tatomir, and Helen Miller, 2018, Business investment, cost of capital and uncertainty in the United Kingdom evidence from firm-level analysis, Bank of England working papers 717, Bank of England.

Rajan, Raghuram and Luigi Zingales, 1998, Financial Dependence and Growth, American Economic Review 88.3, 559-86. 
Figure 1: investment ratio of NFCs: macro series vs sample aggregate

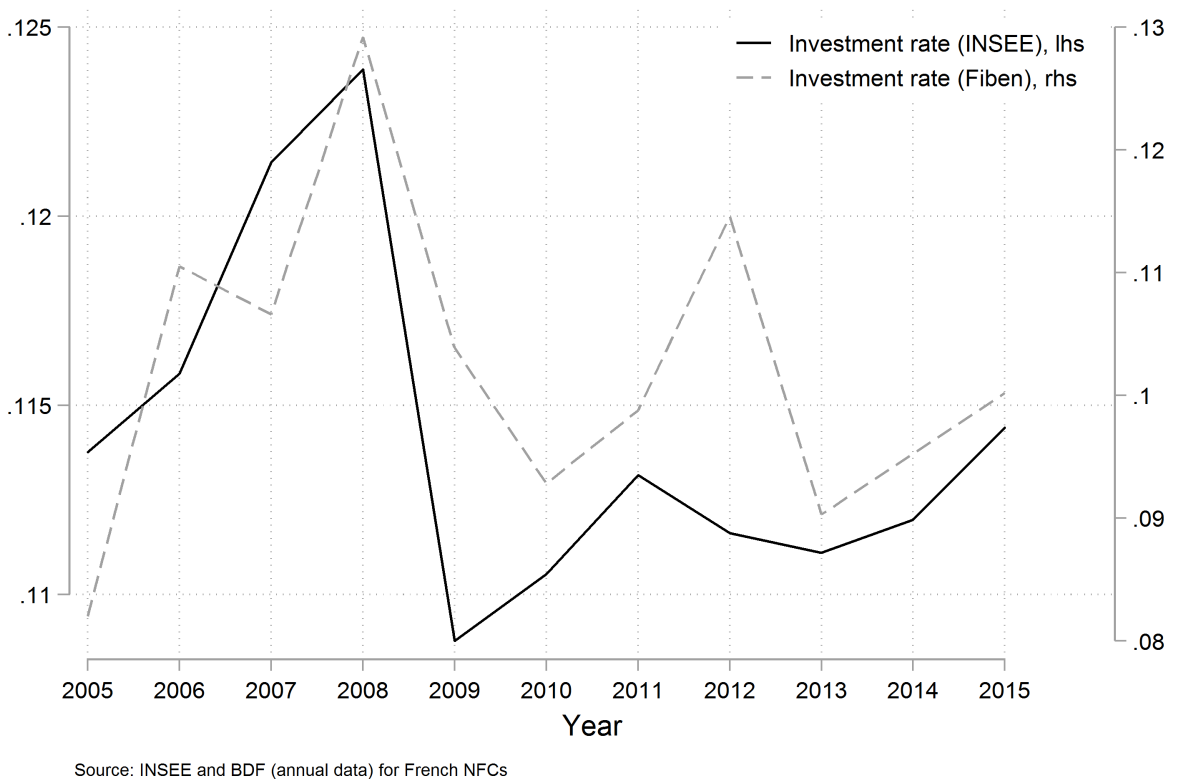

Source: INSEE and BDF (annual data) for French NFCs

Figure 2: WACC at sector-level (Real vs Nominal)
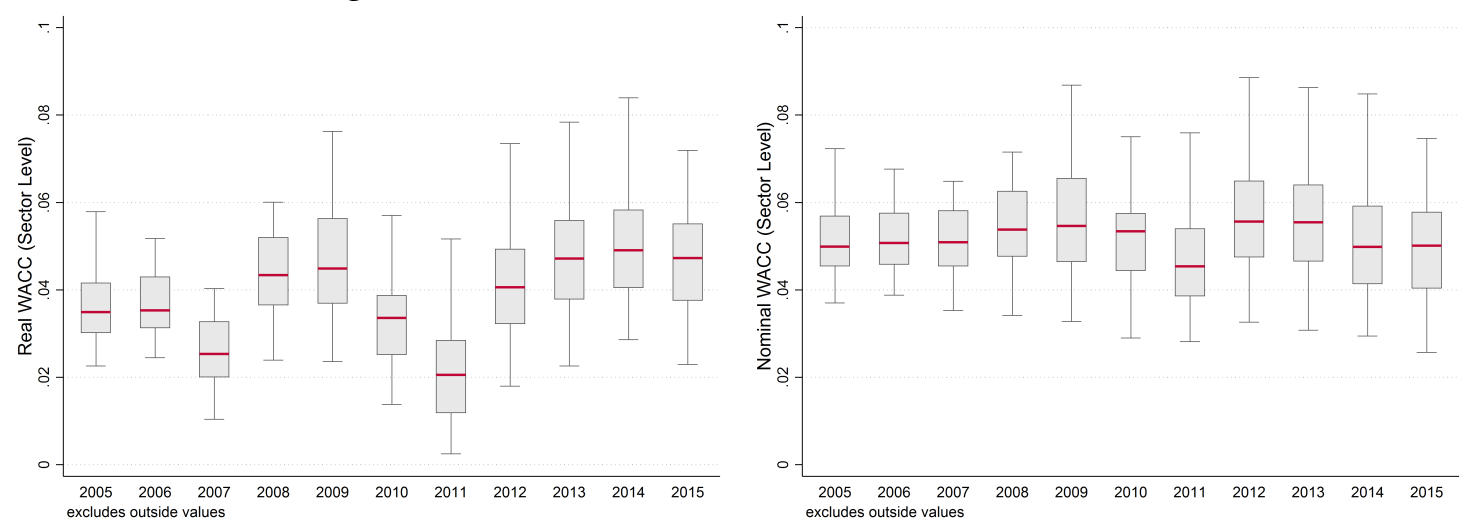
Figure 3: Cost of equity at sector-level (Real vs Nominal)
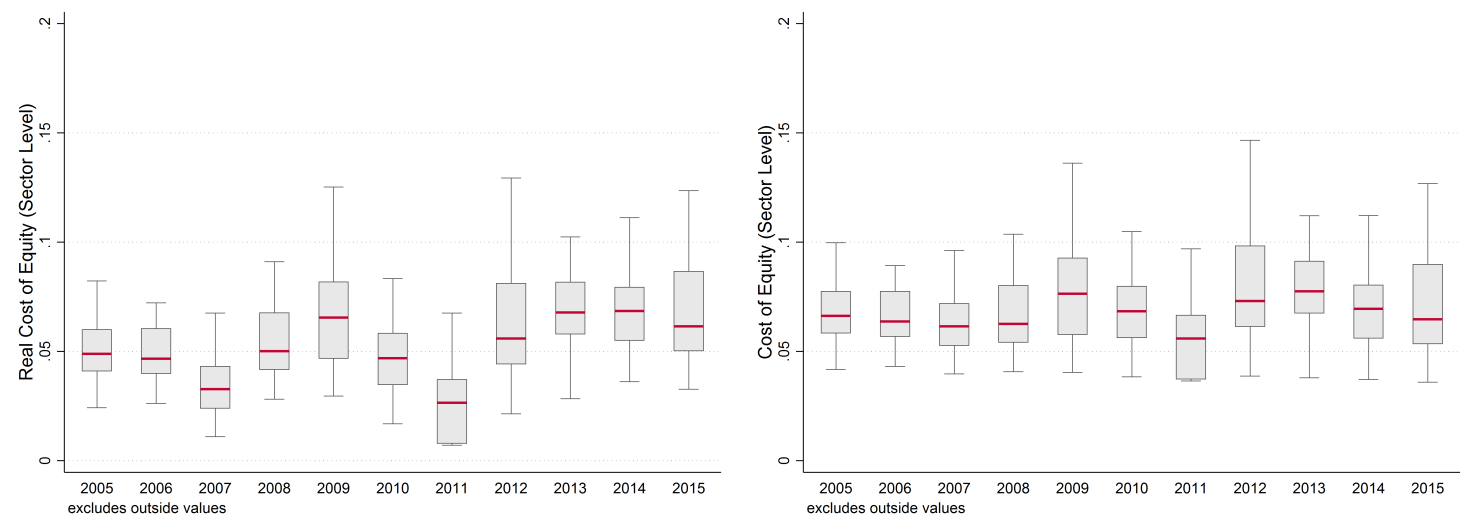

Figure 4: Cost of debt at sector-level (Real vs Nominal)
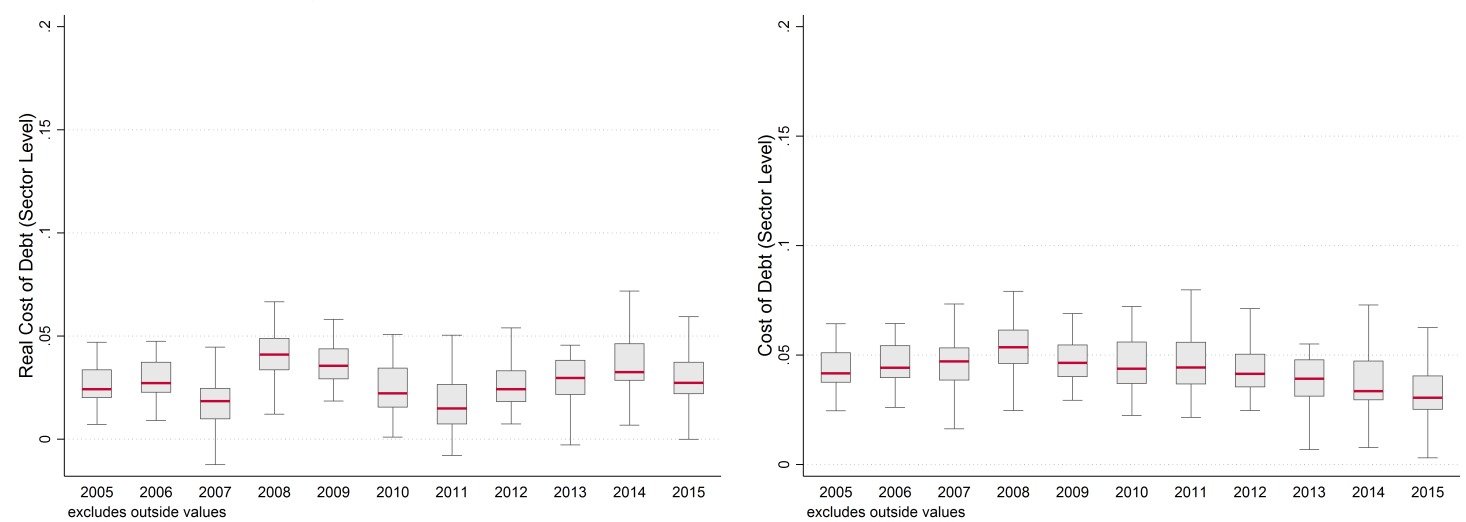
Figure 5: Firm sales concentration at A38 sector-level (Sector Herfinhdal)

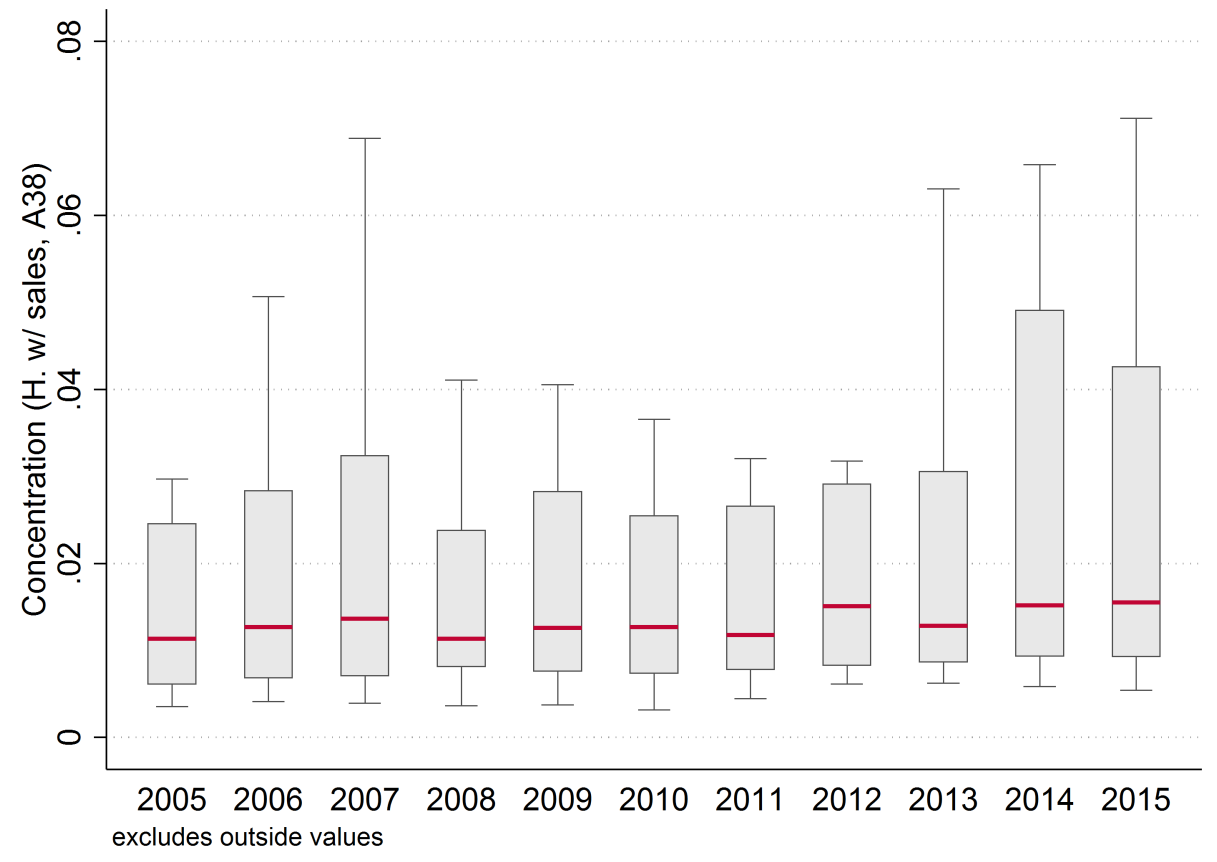

Figure 6: Uncertainty at A38 sector-level

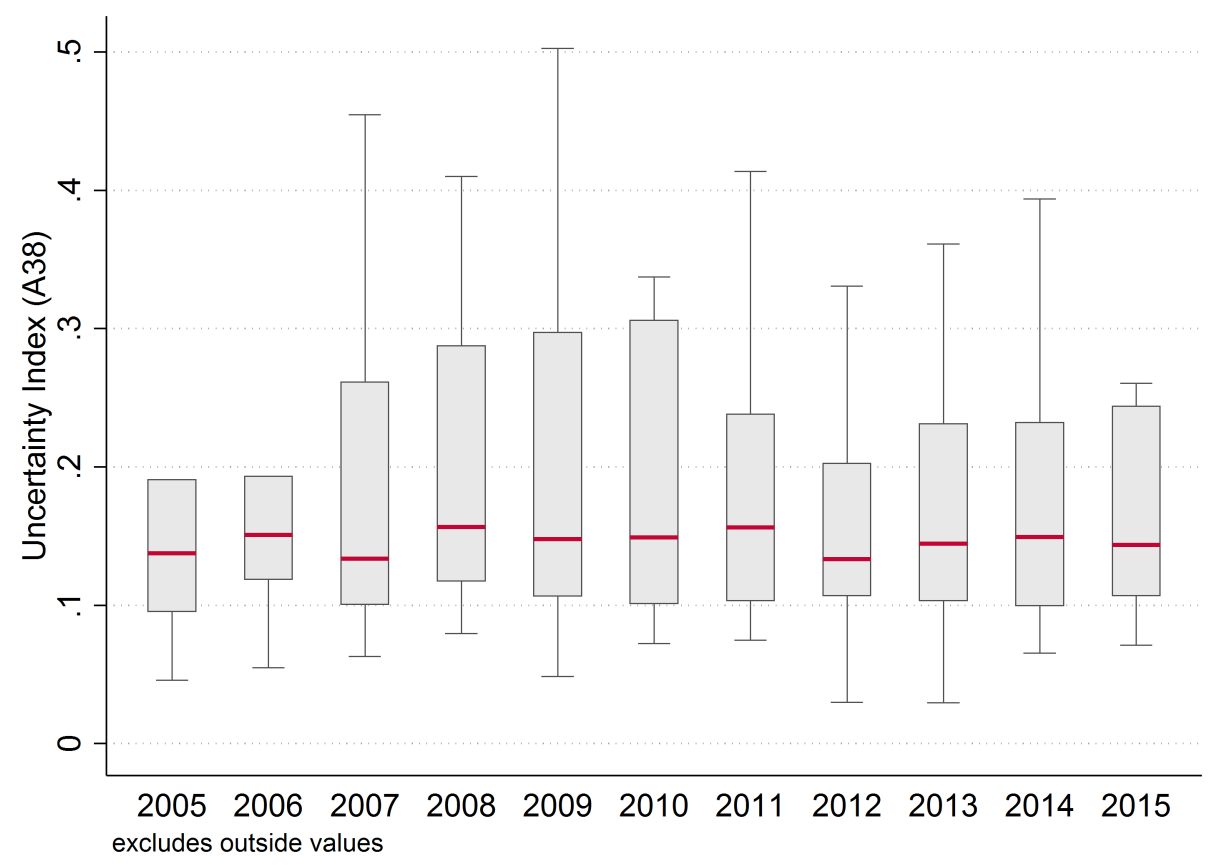


Table 1: Descriptive statistics

\begin{tabular}{|c|c|c|c|c|c|c|c|c|}
\hline & Nb.Obs. & Mean & Std.Dev. & p10 & $\mathrm{p} 25$ & Median & p75 & p90 \\
\hline Investment rate $\left(I / F A_{t-1}\right)$ & 8119 & 0.129 & 0.125 & 0.026 & 0.051 & 0.092 & 0.161 & 0.268 \\
\hline Net Investment rate $\left(N I / F A_{t-1}\right)$ & 8119 & 0.051 & 0.169 & -0.064 & -0.023 & 0.017 & 0.082 & 0.194 \\
\hline Depreciation rate $\delta\left(D E P / F A_{t-1}\right)$ & 8119 & 0.106 & 0.099 & 0.033 & 0.057 & 0.084 & 0.125 & 0.191 \\
\hline Cash-flows to Fixed Assets $\left(O I B D P / F A_{t-1}\right)$ & 8119 & 0.313 & 0.410 & 0.072 & 0.129 & 0.207 & 0.342 & 0.589 \\
\hline Sales growth & 8119 & 0.042 & 0.134 & -0.088 & -0.018 & 0.037 & 0.099 & 0.179 \\
\hline Firm size (TA, in M euros) & 8119 & 1032.098 & 10832.771 & 21.789 & 35.206 & 67.802 & 173.349 & 478.818 \\
\hline Leverage (Debt / Equity + Debt) & 8119 & 0.417 & 0.209 & 0.130 & 0.258 & 0.422 & 0.570 & 0.696 \\
\hline Tax rate $\tau$ (Apparent, sector level) & 8119 & 0.308 & 0.125 & 0.230 & 0.273 & 0.304 & 0.340 & 0.365 \\
\hline Nominal Cost of Debt (CoD) & 8119 & 0.043 & 0.042 & 0.017 & 0.026 & 0.037 & 0.050 & 0.069 \\
\hline Nominal CoD $*(1-\tau)$ & 8119 & 0.030 & 0.030 & 0.012 & 0.018 & 0.026 & 0.035 & 0.048 \\
\hline Nominal Cost of Equity & 8119 & 0.078 & 0.027 & 0.055 & 0.061 & 0.071 & 0.089 & 0.122 \\
\hline Nominal WACC & 8119 & 0.056 & 0.019 & 0.036 & 0.043 & 0.053 & 0.065 & 0.080 \\
\hline Real Cost of Debt & 8119 & 0.029 & 0.042 & 0.002 & 0.012 & 0.023 & 0.036 & 0.054 \\
\hline Real Cost of Equity (CoE) & 8119 & 0.064 & 0.030 & 0.032 & 0.046 & 0.058 & 0.077 & 0.100 \\
\hline Real CoD $*(1-\tau)$ & 8119 & 0.020 & 0.030 & 0.001 & 0.008 & 0.016 & 0.025 & 0.038 \\
\hline Real WACC & 8119 & 0.044 & 0.020 & 0.021 & 0.030 & 0.041 & 0.053 & 0.069 \\
\hline
\end{tabular}

Note. Sample of 1,847 corporate groups (firms) present at least 3 consecutive years over 2005-2015, of which only

182 are listeds. Gross investment: acquisitions minus cession of fixed assets, net investment: gross investment minus depreciation and amortization, Cash-flows: Operating Income Before Depreciation (EBITDA), CoD is the

(firm-specific) implied cost of debt: interest payments normalized by gross long-term debt and leverage: $\mathrm{D} /(\mathrm{D}+\mathrm{E})$.

CoE: computed at the sector level for 49 sectors with a DDM H-Model. Nominal returns are deflated using the french (core HICP) yoy inflation. 
Table 2: Corporate investment and the WACC: baseline

\begin{tabular}{|c|c|c|c|c|c|}
\hline & \multicolumn{5}{|c|}{$\mathrm{I} / \mathrm{FA}$} \\
\hline & (1) & (2) & (3) & (4) & (5) \\
\hline Cash Flow (-1) & $\begin{array}{c}0.060^{* * *} \\
{[0.014]}\end{array}$ & $\begin{array}{c}0.059^{* * *} \\
{[0.015]}\end{array}$ & $\begin{array}{c}0.059^{* * *} \\
{[0.015]}\end{array}$ & $\begin{array}{c}0.060^{* * *} \\
{[0.015]}\end{array}$ & $\begin{array}{c}0.060^{* * *} \\
{[0.015]}\end{array}$ \\
\hline Real WACC (-1) & $\begin{array}{c}-0.266^{* * *} \\
{[0.099]}\end{array}$ & $\begin{array}{c}-0.329^{* *} \\
{[0.130]}\end{array}$ & & & \\
\hline $\mathrm{CoD} *(1-\tau)(-1)$ & & & $\begin{array}{c}-0.288^{* * *} \\
{[0.059]}\end{array}$ & & \\
\hline $\mathrm{CoE}(-1)$ & & & & $\begin{array}{c}-0.178^{* *} \\
{[0.073]}\end{array}$ & \\
\hline Lev. ${ }^{*} \mathrm{CoD} *(1-\tau)(-1)$ & & & & & $\begin{array}{c}-1.377^{* * *} \\
{[0.317]}\end{array}$ \\
\hline$(1-$ Lev. $) * \operatorname{CoE}(-1)$ & & & & & $\begin{array}{c}-0.172 \\
{[0.140]}\end{array}$ \\
\hline Leverage (-1) & $\begin{array}{c}-0.204^{* * *} \\
{[0.022]}\end{array}$ & $\begin{array}{c}-0.199^{* * *} \\
{[0.024]}\end{array}$ & $\begin{array}{c}-0.196^{* * *} \\
{[0.022]}\end{array}$ & $\begin{array}{c}-0.181^{* * *} \\
{[0.022]}\end{array}$ & $\begin{array}{c}-0.182^{* * *} \\
{[0.024]}\end{array}$ \\
\hline Sales growth $(-1)$ & $\begin{array}{l}0.022^{* *} \\
{[0.011]}\end{array}$ & $\begin{array}{l}0.022^{* *} \\
{[0.011]}\end{array}$ & $\begin{array}{l}0.023^{* *} \\
{[0.011]}\end{array}$ & $\begin{array}{l}0.021^{* *} \\
{[0.011]}\end{array}$ & $\begin{array}{l}0.024^{* *} \\
{[0.011]}\end{array}$ \\
\hline Size $(-1)$ & $\begin{array}{c}-0.070^{* * *} \\
{[0.010]}\end{array}$ & $\begin{array}{c}-0.074^{* * *} \\
{[0.013]}\end{array}$ & $\begin{array}{c}-0.075^{* * *} \\
{[0.013]}\end{array}$ & $\begin{array}{c}-0.073^{* * *} \\
{[0.013]}\end{array}$ & $\begin{array}{c}-0.076^{* * *} \\
{[0.013]}\end{array}$ \\
\hline Concentration $(-1)$ & $\begin{array}{c}0.135 \\
{[0.195]}\end{array}$ & $\begin{array}{c}0.129 \\
{[0.194]}\end{array}$ & $\begin{array}{c}0.107 \\
{[0.198]}\end{array}$ & $\begin{array}{c}0.135 \\
{[0.194]}\end{array}$ & $\begin{array}{c}0.109 \\
{[0.194]}\end{array}$ \\
\hline Uncertainty (-1) & $\begin{array}{c}0.009 \\
{[0.018]}\end{array}$ & $\begin{array}{c}0.010 \\
{[0.018]}\end{array}$ & $\begin{array}{c}0.010 \\
{[0.018]}\end{array}$ & $\begin{array}{c}0.010 \\
{[0.018]}\end{array}$ & $\begin{array}{c}0.011 \\
{[0.018]}\end{array}$ \\
\hline Firm FE & Yes & Yes & Yes & Yes & Yes \\
\hline Year FE & No & Yes & Yes & Yes & Yes \\
\hline Other controls & Yes & Yes & Yes & Yes & Yes \\
\hline Observations & 8,119 & 8,119 & 8,119 & 8,119 & 8,119 \\
\hline Adj. R2 & 0.46 & 0.46 & 0.46 & 0.46 & 0.46 \\
\hline
\end{tabular}

Note. OLS regressions. Sample period: 2005-2015. Unbalanced panel of all firms in our sample. Dependent variable: gross fixed capital investment rate $\left(I / F A_{-1}\right)$. Other included controls are the lagged depreciation rate and a dummy for mergers and acquisitions (both coefficients are always non-significant). Standard errors in parentheses are clustered at the firm level. 
Table 3: Corporate investment and the WACC: firm size, industry, financial frictions

\begin{tabular}{|c|c|c|c|c|c|c|c|}
\hline & & & & I/FA & & & \\
\hline & (1) & (2) & (3) & (4) & $(5)$ & (6) & (7) \\
\hline & All & Manuf & Retail & Large & SME & All & All \\
\hline Cash Flow (-1) & $\begin{array}{c}0.059^{* * *} \\
{[0.015]}\end{array}$ & $\begin{array}{c}0.108^{* * *} \\
{[0.025]}\end{array}$ & $\begin{array}{c}0.055 \\
{[0.039]}\end{array}$ & $\begin{array}{c}0.074^{* * *} \\
{[0.016]}\end{array}$ & $\begin{array}{c}0.028 \\
{[0.028]}\end{array}$ & $\begin{array}{c}0.060^{* * *} \\
{[0.014]}\end{array}$ & $\begin{array}{c}0.060^{* * *} \\
{[0.015]}\end{array}$ \\
\hline Real WACC (-1) & $\begin{array}{c}-0.329^{* *} \\
{[0.130]}\end{array}$ & $\begin{array}{c}-0.487^{* *} \\
{[0.199]}\end{array}$ & $\begin{array}{c}-0.027 \\
{[0.251]}\end{array}$ & $\begin{array}{c}-0.283^{* *} \\
{[0.133]}\end{array}$ & $\begin{array}{c}-0.439 \\
{[0.350]}\end{array}$ & $\begin{array}{c}-0.269^{* *} \\
{[0.132]}\end{array}$ & $\begin{array}{l}-0.228^{*} \\
{[0.130]}\end{array}$ \\
\hline WACC $x$ High Lev. $(-1)$ & & & & & & $\begin{array}{c}-0.552^{* * *} \\
{[0.153]}\end{array}$ & \\
\hline WACC x High Fin. Dep. (-1) & & & & & & & $\begin{array}{l}-0.395^{*} \\
{[0.209]}\end{array}$ \\
\hline Leverage (-1) & $\begin{array}{c}-0.199^{* * *} \\
{[0.024]}\end{array}$ & $\begin{array}{c}-0.180^{* * *} \\
{[0.029]}\end{array}$ & $\begin{array}{c}-0.215^{* * *} \\
{[0.043]}\end{array}$ & $\begin{array}{c}-0.145^{* * *} \\
{[0.023]}\end{array}$ & $\begin{array}{c}-0.356^{* * *} \\
{[0.056]}\end{array}$ & $\begin{array}{c}-0.175^{* * *} \\
{[0.025]}\end{array}$ & $\begin{array}{c}-0.203^{* * *} \\
{[0.024]}\end{array}$ \\
\hline Sales growth $(-1)$ & $\begin{array}{l}0.022^{* *} \\
{[0.011]}\end{array}$ & $\begin{array}{c}0.003 \\
{[0.016]}\end{array}$ & $\begin{array}{l}0.035^{* *} \\
{[0.016]}\end{array}$ & $\begin{array}{l}0.028^{* *} \\
{[0.012]}\end{array}$ & $\begin{array}{c}0.006 \\
{[0.019]}\end{array}$ & $\begin{array}{l}0.022^{* *} \\
{[0.011]}\end{array}$ & $\begin{array}{l}0.021^{* *} \\
{[0.011]}\end{array}$ \\
\hline Size $(-1)$ & $\begin{array}{c}-0.074^{* * *} \\
{[0.013]}\end{array}$ & $\begin{array}{c}-0.070^{* * *} \\
{[0.020]}\end{array}$ & $\begin{array}{c}-0.044^{* *} \\
{[0.020]}\end{array}$ & $\begin{array}{c}-0.086^{* * *} \\
{[0.015]}\end{array}$ & $\begin{array}{c}-0.062^{* *} \\
{[0.027]}\end{array}$ & $\begin{array}{c}-0.073^{* * *} \\
{[0.013]}\end{array}$ & $\begin{array}{c}-0.074^{* * *} \\
{[0.013]}\end{array}$ \\
\hline Depreciation rate $\delta(-1)$ & $\begin{array}{c}0.025 \\
{[0.051]}\end{array}$ & $\begin{array}{c}0.034 \\
{[0.052]}\end{array}$ & $\begin{array}{c}-0.162^{*} \\
{[0.086]}\end{array}$ & $\begin{array}{c}0.079 \\
{[0.060]}\end{array}$ & $\begin{array}{c}-0.090 \\
{[0.083]}\end{array}$ & $\begin{array}{c}0.024 \\
{[0.051]}\end{array}$ & $\begin{array}{c}0.025 \\
{[0.051]}\end{array}$ \\
\hline M\&A dummy & $\begin{array}{c}0.007 \\
{[0.010]}\end{array}$ & $\begin{array}{c}0.012 \\
{[0.015]}\end{array}$ & $\begin{array}{c}0.007 \\
{[0.017]}\end{array}$ & $\begin{array}{c}-0.000 \\
{[0.009]}\end{array}$ & $\begin{array}{c}0.037 \\
{[0.044]}\end{array}$ & $\begin{array}{c}0.007 \\
{[0.010]}\end{array}$ & $\begin{array}{c}0.007 \\
{[0.010]}\end{array}$ \\
\hline Concentration (-1) & $\begin{array}{c}0.129 \\
{[0.194]}\end{array}$ & $\begin{array}{c}0.307 \\
{[0.264]}\end{array}$ & $\begin{array}{c}2.864 \\
{[2.398]}\end{array}$ & $\begin{array}{c}0.009 \\
{[0.147]}\end{array}$ & $\begin{array}{l}1.567^{* *} \\
{[0.753]}\end{array}$ & $\begin{array}{c}0.158 \\
{[0.187]}\end{array}$ & $\begin{array}{c}0.132 \\
{[0.198]}\end{array}$ \\
\hline Uncertainty $(-1)$ & $\begin{array}{c}0.010 \\
{[0.018]}\end{array}$ & $\begin{array}{c}-0.015 \\
{[0.043]}\end{array}$ & $\begin{array}{c}0.000 \\
{[.]}\end{array}$ & $\begin{array}{c}0.022 \\
{[0.022]}\end{array}$ & $\begin{array}{c}0.015 \\
{[0.032]}\end{array}$ & $\begin{array}{c}0.010 \\
{[0.018]}\end{array}$ & $\begin{array}{c}0.010 \\
{[0.018]}\end{array}$ \\
\hline Firm FE & Yes & Yes & Yes & Yes & Yes & Yes & Yes \\
\hline Year FE & Yes & Yes & Yes & Yes & Yes & Yes & Yes \\
\hline Observations & 8,119 & 3,323 & 3,159 & 5,332 & 2,661 & 8,119 & 8,119 \\
\hline Adj. R2 & 0.46 & 0.36 & 0.30 & 0.52 & 0.39 & 0.46 & 0.46 \\
\hline
\end{tabular}

Note. OLS regressions. Sample period: 2005-2015. Unbalanced panel of all firms in our sample. Dependent variable: gross fixed capital investment rate $\left(I / F A_{-1}\right)$. SMEs: staff $<250$ and sales $<50 \mathrm{M}$ euros (or assets $<$ $43 \mathrm{M}$ euros). Larger firms: above these thresholds. High leverage (in year $t$ ) is a dummy for firms in the upper quartile of the leverage distribution of year $t$. High Financial Dependence is a dummy for firms in the upper half of industrial sectors according to a Rajan-Zingales index of financial dependence computed using UK firm-level data over 1993-2003. Standard errors in parentheses are clustered at the firm level. 
Table 4: Corporate investment and the WACC: GMM robustness

\begin{tabular}{|c|c|c|c|c|}
\hline & \multicolumn{2}{|c|}{ OLS } & \multicolumn{2}{|c|}{ GMM } \\
\hline & (1) & (2) & (3) & (4) \\
\hline & All & All & All & $\geq 2009$ \\
\hline \multirow[t]{2}{*}{ Cash Flow (-1) } & $0.074^{* *}$ & $0.079^{* * *}$ & $0.073^{* *}$ & $0.085^{* *}$ \\
\hline & {$[0.030]$} & {$[0.029]$} & [0.031] & {$[0.040]$} \\
\hline \multirow[t]{2}{*}{ Real WACC (-1) } & -0.266 & -0.182 & $-1.703^{* *}$ & $-1.588^{* *}$ \\
\hline & {$[0.198]$} & [0.147] & {$[0.681]$} & {$[0.667]$} \\
\hline \multirow[t]{2}{*}{ Leverage $(-1)$} & $-0.240^{* * *}$ & $-0.237^{* * *}$ & $-0.399^{* * *}$ & $-0.404^{* * *}$ \\
\hline & {$[0.043]$} & {$[0.041]$} & {$[0.101]$} & [0.118] \\
\hline \multirow[t]{2}{*}{ Sales growth $(-1)$} & -0.007 & -0.007 & -0.024 & -0.021 \\
\hline & [0.019] & [0.019] & {$[0.020]$} & {$[0.021]$} \\
\hline \multirow[t]{2}{*}{ Size $(-1)$} & $-0.070^{* * *}$ & $-0.073^{* * *}$ & $-0.041^{* *}$ & -0.030 \\
\hline & {$[0.015]$} & {$[0.013]$} & {$[0.019]$} & {$[0.022]$} \\
\hline \multirow[t]{2}{*}{ Depreciation rate $\delta(-1)$} & -0.078 & -0.085 & -0.046 & -0.042 \\
\hline & {$[0.100]$} & {$[0.100]$} & {$[0.100]$} & [0.107] \\
\hline \multirow[t]{2}{*}{ M\&A dummy } & -0.019 & -0.019 & -0.020 & $-0.027^{* *}$ \\
\hline & {$[0.012]$} & [0.012] & {$[0.013]$} & {$[0.012]$} \\
\hline \multirow[t]{2}{*}{ Concentration (-1) } & -0.100 & -0.071 & -0.087 & 0.262 \\
\hline & {$[0.121]$} & [0.112] & [0.137] & {$[0.338]$} \\
\hline \multirow[t]{2}{*}{ Uncertainty (-1) } & -0.017 & -0.019 & -0.012 & -0.005 \\
\hline & [0.019] & [0.019] & [0.020] & {$[0.020]$} \\
\hline Firm FE & Yes & Yes & Yes & Yes \\
\hline Year FE & Yes & No & No & No \\
\hline Macro controls & No & Yes & Yes & Yes \\
\hline Observations & 2,798 & 2,798 & 2,798 & 2,550 \\
\hline Adj. R2 & 0.45 & 0.45 & 0.41 & 0.43 \\
\hline KP LM stat. p-val. & & & 0.00 & 0.00 \\
\hline KP Wald F-stat. & & & 15.92 & 18.06 \\
\hline Hansen-J p-val. & & & 0.56 & 0.79 \\
\hline
\end{tabular}

Note. OLS regressions (columns 1-2), GMM regressions (col. 3-8). Sample period: 2005-2015, but the presence of up to 4 lags of the WACC implies that most of the pre-2009 observations are actually dropped in the regressions with firm fixed effects. Unbalanced panel of all firms in our sample. Dependent variable: gross fixed capital investment rate $\left(I / F A_{-1}\right)$. SMEs: staff $<250$ and sales $<50 \mathrm{M}$ euros (or assets $<43 \mathrm{M}$ euros). Larger firms: above these thresholds. Macro controls in columns (2-8)are lagged GDP growth and the lag of the VSTOXX (in logs). In the GMM regressions, the first lag of the WACC is instrumented by lags 3 and 4 of the WACC and the first lag of leverage is instrumented by lags 2 and 3 of leverage (all in levels). KP LM stat. p-val. stands for the p-value of the Kleibergen-Paap statistic of underidentification. KP Wald F-stat. stands for the F-statistics of the Kleibergen-Paap Wald test of weak instruments. Hansen-J p-val. is the p-value of the Hansen J-statistic of over identification. Standard errors in parentheses are clustered at the firm level. 